NBER WORKING PAPER SERIES

\title{
EQUILIBRIUM IMPOTENCE: \\ WHY THE STATES AND NOT THE AMERICAN NATIONAL GOVERNMENT FINANCED ECONOMIC DEVELOPMENT IN THE ANTEBELLUM ERA
}

\author{
John Joseph Wallis \\ Barry R. Weingast \\ Working Paper 11397 \\ http://www.nber.org/papers/w11397 \\ NATIONAL BUREAU OF ECONOMIC RESEARCH \\ 1050 Massachusetts Avenue \\ Cambridge, MA 02138 \\ June 2005
}

Professor, Department of Economics, University of Maryland and Research Associate, National Bureau if Economic Research; and Senior Fellow, Hoover Institution, and Ward C. Krebs Family Professor, Department of Political Science, Stanford University. This research was undertaken while Wallis was a National Fellow at the Hoover Institution whose generous support is acknowledged. The authors gratefully acknowledge Daniel Carpenter, Brad DeLong, Martha Derthick, Morris Fiorina, Douglas Grob, Michael Holt, Gary Libecap, Douglass North, Wally Oates, Christina Romer, Kenneth Shepsle, Richard Steckel, Steve Usselman, Richard White, Brian Knight, Roger Gordon, Dennis Epple, and seminars at the NBER Development of the American Economy program meeting, the 2004 EHA meetings, and the Public Economics program and NBER for helpful conversations. The views expressed herein are those of the author(s) and do not necessarily reflect the views of the National Bureau of Economic Research.

(C2005 by John Joseph Wallis and Barry R. Weingast. All rights reserved. Short sections of text, not to exceed two paragraphs, may be quoted without explicit permission provided that full credit, including (C) notice, is given to the source. 
Equilibrium Impotence: Why the States and Not the American National Government Financed Economic Development in the Antebellum Era

John Joseph Wallis and Barry R. Weingast

NBER Working Paper No. 11397

June 2005

JEL No. N0, N4, N7, H1, H2, H5, H7

\begin{abstract}
$\underline{\text { ABSTRACT }}$
Why did states dominate investments in economic development in early America? Between 1787 and 1860, the national government's \$54 million on promoting transportation infrastructure while the states spent $\$ 450$ million. Using models of legislative choice, we show that Congress could not finance projects that provided benefits to a minority of districts while spreading the taxes over all. Although states faced the same political problems, they used benefit taxation schemes - for example, by assessing property taxes on the basis of the expected increase in value due to an infrastructure investment. The U.S. Constitution prohibited the federal government from using benefit taxation. Moreover, the federal government's expenditures were concentrated in collections small projects - such as lighthouses and rivers and harbors - that spent money in all districts. Federal inaction was the result of the equilibrium political forces in Congress, and hence an equilibrium impotence.

John Joseph Wallis Department of Economics University of Maryland College Park, MD 20742

and NBER

wallis@econ.umd.edu

Barry R. Weingast

Stanford University weingast@stanford.edu
\end{abstract}




\section{Introduction}

American governments devoted substantial resources to promoting economic development before the Civil War. The United States was an agrarian economy with millions of acres of virgin land. Economic growth required investment in transportation (roads, canals, and railroads) to open frontier land to markets and in banks to finance shipment of goods to markets. Governments financed both financial institutions and large-scale internal improvements [Callender 1903, Goodrich 1960, North 1966, Taylor 1968, Larson 2001].

The puzzle is that state, not the national, governments played the central role as promoters of development. Indeed, state financial efforts were nearly an order of magnitude larger than the federal government's. Between 1790 and 1860, the federal government spent $\$ 60$ million on transportation improvements, while state and local governments spent over $\$ 450$ million. ${ }^{1}$ Every American is a citizen of both a state and the United States. Given the demand for public goods to promote development, why did the states and not the national government supply these public goods?

Several other aspects of early America make the contrast more puzzling. First, the national government should be more efficient provider of infrastructure. The nation as a whole is better able to spread the risks of such an investment than an individual state, an explanation often used to justify the modern leadership of the national government in economic policy. Second, the national government typically ran a budget surplus in peacetime before 1860 , so fiscal

${ }^{1}$ Government expenditures in total were a small part of total income in the early nineteenth century, on the order of 5 percent of national income [Wallis, 2000]. Between 1800 and 1860 the total federal expenditures, including war expenditures, were $\$ 1,673$ million. State and local transportation expenditures were fully one quarter of total federal expenditures. 
constraints played a limited role in the national government's failure to provide these marketenhancing public goods. ${ }^{2}$

Our specific puzzle is related to a third issue. The national Constitution created a government of limited powers, including a strong system of federalism, a system that pitted "ambition against ambition." Did the incentives facing public officials limit their ability to exercise political power?

To address these questions, we model the political economy of a legislature facing the choice of funding a large infrastructure investment. The model has three related results. First, the political constraints inherent in majority rule prevented the federal government from financing large infrastructure projects. Large projects provided geographically highly concentrated benefits with diffuse costs. Because such projects increased taxation everywhere, they made most areas of the country worse off and so could not command a majority of votes. Although logrolling was possible, in practice the scale of infrastructure investments like the Erie Canal limited logrolling because only a few could be built at once.

Second, two separate political forces pushed Congress toward financing large collections of smaller projects - such as lighthouses, roads, or dredging harbors - distributed across the entire country. We term these large collections "universalism," or "something for everyone." Coalitional politics push toward universalism [Weingast 1979]. When members of Congress are uncertain about what winning coalition that will form, a universal coalition provides higher

${ }^{2}$ Federal government finances were tight during the 1790s and during the War of 1812 . In 1815 the national debt was $\$ 137$ million; by 1835 it was paid off completely. In the 1820 s, annual federal revenues averaged \$22 million and expenditures only \$16 million; in the 1830s, $\$ 30$ million and \$24 million. Historical Statistics of the United States. 
expected returns to each district and its representative than narrower majority coalitions. The second force, the exit constraint -- the idea that states would leave the Union if federal policies left them significantly worse off -- also pushed toward universalism. As we note below, exit was a serious threat in early America: southern states seceded in 1861. The exit constraint implies that narrow majority coalitions, especially regional ones, risk secession by the areas locked out of power. Universalism emerged as the natural solution to both the majority constraint and the exit constraint.

Third, we show that benefit, or Lindahl, taxation provided another solution to these political constraints. If the government can tax each locality or state in proportion to the benefits it receives from the project, then regions outside the area benefitting from the project pay no taxes and so will not oppose it. The Constitution prohibits the federal government - but not the states - from using benefit taxation to finance projects: it requires that federal direct taxes be assessed among the states on the basis of population.

These results explain the puzzles noted above. The state and national governments persistently financed development projects in different ways. The Constitutional prohibition on benefit taxation combines with the logic of congressional politics to imply that the federal government could not finance large projects. To the extent that the national government financed transportation investment, it did so through something for everyone programs. In contrast, states financed large projects using benefit taxes, assessing property owners in proportion to their expected economic gains from the new project. This mechanism allowed them to solve the same political problems that plagued the national government. 
Finally, these results bear on our larger question about the incentives for how limits on the power of the national government operated in early America. The Constitution created a series of political constraints that made it politically impossible for the federal government to finance large infrastructure projects. Federal efforts came either in form of financing large collections of small projects or formal allocation formulas to distribute funds to every state. In short, the national government was politically impotent with respect to the provision of the highest valued infrastructure projects.

Section 2 of the paper develops the theory of legislative choice and derives our results about state and federal policy decisions. Sections 3 and 4 apply these results to the antebellum era's national and state programs to finance economic development. Sections 5 and 6 consider federal policy in more detail. Section 7 discusses the implications of our approach to address the question of why the federal government grew so much in the twentieth century.

\section{A Theory of Legislative Choice and Infrastructure Investment}

We turn to the theory of legislative choice to understand the three phenomena to be explained: the federal government's inability to promote economic development through financing large infrastructure projects; its ability to finance many small projects; and why the states were not plagued by the same problems.

Today we think of the president as the national leader, the source of most major legislative initiatives. Yet this is a product of the twentieth century. In the nineteenth century, 
Congress was at the center stage of national legislation. All the famous compromises that revised aspects of the American national framework and helped sustain the United States were negotiated and written in Congress, including those of 1820, 1833, 1850, and 1877.

We consider those nineteenth century policies which sought to spend revenue to build transportation links: roads, canals and, later, railroads, as wells as rivers and harbors projects and lighthouses. The model applies to both the American federal and state governments, so we talk about generic legislatures and districts, rather than states, districts, or counties. Both Congress and state legislatures are geographically oriented. ${ }^{3}$ Because legislators are elected from specific geographic constituencies their electoral incentives force them to concern themselves about the incidence of policies on their district. Although national or statewide interests matter, it is primarily the effects of policies on their district that determine whether a given member favors a policy [Stewart 2002].

Consider an expenditure policy to provide a public good, $\pi(\mathrm{x})=\left(\mathrm{P}_{1}(\mathrm{x}), \mathrm{P}_{2}(\mathrm{x}), \ldots, \mathrm{P}_{\mathrm{n}}(\mathrm{x})\right)$ where $\mathrm{n}$ is the number of districts, $\pi(\mathrm{x})$ is a public policy, and the $\mathrm{P}_{\mathrm{i}}(\mathrm{x})$ represent the incidence of the policy on district $\mathrm{i}^{4}$ The various functions are written as a function of $\mathrm{x}$, a scale factor that reflects the size of the policy.

${ }^{3}$ This discuss draws on modern theories of congressional decisionmaking, particularly in a historical context. See, e.g., Aldrich [1995], Cox and McCubbins [1993,2005], Krehbiel [1994], Polsby [2004], Rohde [1991], Schickler [2001], Stewart [2001], Shepsle [1989], Weingast and Marshall [1988].

${ }^{4}$ In what follows, we adapt the models in Inman [1988], Shepsle and Weingast [1984] and Weingast, Shepsle, and Johnsen [1981]. It is quite possible that the perceived costs and benefits of programs will differ at the national and state level because of externalities, both positive and negative. We abstract from those concerns in this paper. 
$\mathrm{P}_{\mathrm{i}}(\mathrm{x})$ can be broken into the benefits, $\mathrm{b}_{\mathrm{i}}(\mathrm{x})$, and costs, $\mathrm{c}_{\mathrm{i}}(\mathrm{x})$, where $\mathrm{P}_{\mathrm{i}}(\mathrm{x})=\mathrm{b}_{\mathrm{i}}(\mathrm{x})-\mathrm{c}_{\mathrm{i}}(\mathrm{x})$. We assume that the benefits are concave and the costs are convex as a function of $x$; that is, $b_{i}{ }^{\prime}>0$, $\mathrm{b}_{\mathrm{i}}{ }^{\prime \prime}<0$, and $\mathrm{c}_{\mathrm{i}}{ }^{\prime}>0$ and $\mathrm{c}_{\mathrm{i}}^{\prime \prime}>0 \forall \mathrm{i}$.

The total net social benefits for the state is represented as:

$$
\mathrm{Z}(\mathrm{x})=\sum_{\mathrm{i}} \mathrm{P}_{\mathrm{i}}(\mathrm{x})=\sum_{\mathrm{i}}\left(\mathrm{b}_{\mathrm{i}}(\mathrm{x})-\mathrm{c}_{\mathrm{i}}(\mathrm{x})\right)
$$

The economically efficient policy, $\mathrm{x}^{*}$, is such that at $\mathrm{x}^{*}, \mathrm{Z}^{\prime}=0$ and $\mathrm{Z}^{\prime \prime}<0$ so that at $\mathrm{x}^{*}$ the marginal net social benefits are zero; i.e., $\sum_{\mathrm{i}}\left(\mathrm{b}_{\mathrm{i}}{ }^{\prime}(\mathrm{x})-\mathrm{c}_{\mathrm{i}}{ }^{\prime}(\mathrm{x})\right)=0$. Legislative outcomes are unlikely to meet this criteria, however.

Let $\mathrm{C}=\sum_{\mathrm{i}} \mathrm{c}_{\mathrm{i}}(\mathrm{x})$ be the total costs of the project, and let $\mathrm{T}$ be the total taxes needed to finance the project. We assume a balanced budget constraint, so that $\mathrm{T}=\mathrm{C}$. Further, district i's tax share is $t_{i}$, so that its tax cost for a particular project is $t_{i} C .^{5}$

District i's legislator's objective function is $\mathrm{P}_{\mathrm{i}}(\mathrm{x})=\mathrm{b}_{\mathrm{i}}(\mathrm{x})-\mathrm{t}_{\mathrm{i}} \mathrm{C}(\mathrm{x}) .{ }^{6}$ Legislators consult only their own objective function, ignoring the effects of the project on other districts, and hence the project's social implications. When choosing between two projects, or between building a particular project and not, each legislator supports the alternative that provides higher net benefits. Moreover, we assume a convention about indifference: if a legislator's district bears no

${ }^{5}$ For simplicity, we treat all costs as tax costs, but clearly the costs and benefits to constituents and legislators can come in many forms.

${ }^{6}$ Each legislator $\mathrm{i}$ has an ideal policy of $\mathrm{x}_{\mathrm{i}}{ }^{*}$ which solves the problem $\max \mathrm{P}_{\mathrm{i}}(\mathrm{x})$ and which occurs when the marginal benefits to district $i$ equals the districts costs, i.e., $b_{i}{ }^{\prime}(x)=$ $\mathrm{t}_{\mathrm{i}} \mathrm{C}^{\prime}(\mathrm{x})$. 
costs for a project, she votes in favor even if her district receives no benefits. ${ }^{7}$ It is clearly costless for such a legislator to do so.

Legislatures are constrained in two ways. First, passage of individual legislation is only possible if a majority of legislators benefit from the proposed legislation. ${ }^{8}$ This majority rule constraint applies to individual pieces of legislation. Logrolling makes it possible to fund individual projects (as opposed to legislation) that benefit a minority of legislators, as long as the project is paired with enough other projects that a majority of legislators receive positive net benefits from the entire package. For simplicity, the majority rule constraint requires that all of the necessary logrolls be bundled into one bill.

Second, the exit constraint applies to the aggregate of all legislation passed by the legislature. At the national level, every state must receive positive net benefits from the sum of all legislation passed, or it "exits." The exit constraint requires that no district is hurt, on balance, by the aggregate actions of the government. Threats of exit were common in the early United States. Threats to secede or dramatically weaken the union occurred with the Virginia and Kentucky Resolutions (1798), the Hartford Convention (1815), the Nullification Crisis (1832-

${ }^{7}$ All voting models require an assumption about what happens when a legislator is indifferent between two alternatives.

${ }^{8}$ Given a single dimensional policy choice, such as the choice over the scale of a single project, the majority rule equilibrium is the ideal policy of the median district. Standard results show that, except in very special circumstances, no majority rule equilibrium exists when the legislature chooses the scale of many projects simultaneously. These concepts are defined in Hinich and Munger [1997], Shepsle and Bonchek [1997], and Stewart [2002]. 
33), and the sectional crises of 1819-20 (over Missouri), 1846-50 (over the Mexican Cession), and 1854-61 (following the Kansas-Nebraska Act), which resulted in the Civil War. ${ }^{9}$

The exit constraint requires that:

$$
\sum_{\mathrm{I}} \mathrm{P}_{\mathrm{ij}}(\mathrm{x})>0(\text { summed over j policies, } \forall \mathrm{i}) \text {. }
$$

We will return to consider the historical relevance of both the majority and the exit constraint later. With respect to states, mobile factors of capital and labor will leave the state if some region is a permanent minority that receives too little benefits in comparisons with its taxes.

The legislature must make simultaneous decisions about the size of the project, the allocation of benefits across districts, and the allocation of tax burdens across districts. We characterize legislative outcomes under four different mechanisms of public finance: normal taxation, benefit taxation, universalism or something for everyone, and taxless finance. These categories are not mutually exclusive, nor are they exhaustive, but they give us a framework to discuss the choice set facing Congress and the state legislatures in the early $19^{\text {th }}$ century. We continue to consider one big project, like the Erie canal.

A. One large project: Normal taxation. Normal taxes are the general revenue instruments already in use by the government. In the case of the federal government in the early $19^{\text {th }}$ century, financing expenditures by normal taxation involved revenue from import duties, the national government's principal tax.

Large projects have several relevant characteristics. First, they require very large expenditures relative to the budget, implying that at most only one or two such projects can be

${ }^{9}$ Schlesinger [1922] shows that every state had some secessionist movement prior to the Civil War. See Hendrickson [2003] for a recent treatment of forces leading to disunion in the early nation. 
built at once. Second, these projects concentrate the benefits in a small geographic area while spreading the tax costs across the entire polity. This implies that some districts receive large benefits relative to their tax cost: $b_{i}\left(x^{*}\right)>t_{i} C\left(x^{*}\right)$; but many districts receive no benefits while bearing their tax cost: $\mathrm{P}_{\mathrm{i}}(\mathrm{x})<0 \forall \mathrm{x}>0$, since $\mathrm{b}_{\mathrm{i}}(\mathrm{x})=0$ while $\mathrm{t}_{\mathrm{i}} \mathrm{C}(\mathrm{x})>0$.

The concentration of benefits in a few districts implies that most districts pay taxes while receiving no benefits. These districts both naturally oppose the project and comprise a majority, so the majority rule constraint implies that no project is built. The size of the project makes it impossible to find enough logrolling options to compensate districts that do not gain from the large project. Even if it is possible to find a project that benefits a majority of districts, a simple majority fails to meet the exit constraint. In short, it is difficult for government to build a large, expensive, geographically concentrated project through normal taxation.

B. One large project: Benefit taxation. The first result assumed that the financial costs of the project were spread across the state through general taxation. Suppose instead that the project could be financed by a tax scheme, benefit taxes, also known as Lindahl taxes. In this scheme, district i's tax share is a function of the benefits it receives from the project.

Let the $\mathrm{B}(\mathrm{x})=\sum_{\mathrm{i}} \mathrm{b}_{\mathrm{i}}(\mathrm{x})$ be the project's total benefits. Define a benefit taxation scheme so that $t_{i}=b_{i} / B$. Under this tax scheme, districts that receive no benefits from the project also pay no taxes regardless of the project's total cost: $b_{i}=0$ implies that $t_{i}=0 / B=0$. Districts pay their share in taxes in proportion to the benefits they receive. 
As long as the project's total benefits exceed the total costs $(B>C)$, each district with positive benefits also has positive net benefits after paying their tax share. ${ }^{10}$ Thus, assuming that representatives who are indifferent to the project - including legislators whose districts receive no benefits but also incur no costs - vote in favor of the project, every legislator (weakly) favors the project, so it will pass. In contrast to the case where projects are financed out of general revenue, benefit taxation implies that, even in the case of a large project like the Erie canal, most districts receive no benefits and incur no costs, and so they can costlessly support the project.

The widespread use of the property tax provided states with a potential mechanism for creating a benefit tax. When the value of transportation improvements is capitalized in land values and property taxes are used to fund construction, it is possible for every district to, at worst, be indifferent to the large project. The use of benefit taxation to finance a single large project simultaneously satisfies the majority and exit constraints.

The central problem with a single large project is the inability to balance off the losses to districts that do not benefit from the project because the government is unable to afford multiple large projects. Benefit taxation solves that problem. The Constitution, however, explicitly prohibited the federal government from using benefit taxation: "Representation and direct taxes shall be apportioned among the several States which may be included in this Union, according to their respective Numbers..." (Article 1, Section 2). ${ }^{11}$

${ }^{10} \mathrm{To}$ see that $\mathrm{b}_{\mathrm{i}}>\mathrm{t}_{\mathrm{i}} \mathrm{C}$ under benefit taxation, substitute on the right hand side: $\mathrm{t}_{\mathrm{i}} \mathrm{C}=$ $\left(b_{i} / B\right) C=(C / B) b_{i}$. Since $C / B<1$, the first inequality holds.

${ }^{11}$ The federal government levied a property tax in 1799,1814 , and 1862 , but since the tax had to be allocated between states on the basis of population, it could not be allocated on the basis of benefits as measured in increased wealth or property values. 
C. One large project: Taxless finance. There are several alternatives to financing a project through taxes. These financing schemes share a common element: building the project does not entail raising current taxes, thus taxless finance. ${ }^{12}$ Suppose the canal is expected to generate a stream of toll revenues, but its construction requires government assistance in the form of eminent domain, limited liability, and financial assistance. ${ }^{13}$ The government could charter a company, creating the special privileges, and then use the good faith and credit of the government to secure operating capital by issuing bonds. The government then invests the borrowed funds in the private corporation by purchasing stock. Dividends from the government's investment are expected cover the government's interests costs. Taxpayer's liability in this case were contingent on the success of the project. If the project succeeded, the government received a steady flow of dividends, net of interest costs, allowing it to lower taxes. If the project failed, the government and its taxpayers would assume the debt service. The First and Second Banks of the United States were financed in this manner.

A second method of taxless finance was used extensively by the federal government: land grants. In these schemes, the federal government would give project promoters grants of federal land, in alternating strips along the right of way. Project promoters could sell their land to raise funds. Federal lands were an important source of federal revenue, and the idea was that taxpayers would gain from the grant by raising land values on the land the federal government did not give away. The rise in land values would offset the loss of land revenue from the grant.

\footnotetext{
${ }^{12}$ Taxless finance is considered in greater detail in Wallis, 2005, "Constitutions, Corporations, and Corruption."

${ }^{13}$ Canals required eminent domain and banks required limited liability and, often, the privilege of note issue.
} 
Federal land values had to more than double for this to happen. Grants were made to Ohio, Indiana, and Illinois in the 1820s, and the Union and Central Pacific Railroads in the 1860s.

Taxless finance works politically because of the implicit benefit received by all districts. Current taxes may not rise, but taxpayers do assume an expected, contingent liability:

$$
\mathrm{CL}_{\mathrm{i}}=\mathrm{t}_{\mathrm{i}} \mathrm{C}(\mathrm{x})(1-\mathrm{s})
$$

where $\mathrm{s}$ is the ex ante probability of project success. If the project fails ex post, $\mathrm{CL}_{\mathrm{i}}$ will be positive for all districts. Note that $\mathrm{P}_{\mathrm{i}}(\mathrm{x})$ is negative for any districts who receive no immediate benefits, i.e. for whom $b_{i}(x)=0$.

A taxless finance scheme that does not provide benefits to all districts, ex ante, will have a negative expected value to a majority of districts and will not be supported:

$$
\mathrm{P}_{\mathrm{i}}(\mathrm{x})=\mathrm{b}_{\mathrm{i}}(\mathrm{x})-\mathrm{t}_{\mathrm{i}} \mathrm{C}(\mathrm{x})(1-\mathrm{s})<0 \quad\left(\forall \mathrm{i} \text { where } \mathrm{b}_{\mathrm{i}}(\mathrm{x})=0\right) .
$$

Taxless finance does not work that way, however. The assumption is that the project will return money to the treasury, either in the form of dividends on the government's stock or higher revenues from land sales. If $\mathrm{M}$ represents the potential profit of the enterprise to the government, then the calculation of net benefits for each district becomes:

$$
\mathrm{P}_{\mathrm{i}}(\mathrm{x})=\mathrm{b}_{\mathrm{i}}(\mathrm{x})+\mathrm{t}_{\mathrm{i}} \mathrm{M}(\mathrm{s})-\mathrm{t}_{\mathrm{i}} \mathrm{C}(\mathrm{x})(1-\mathrm{s}) .
$$

That is, each district expects its taxes to go down by $t_{i} M$ if the project is successful. The critical issue for districts who do not benefit directly from the canal, districts where $b_{i}(x)=0$, is whether $\mathrm{t}_{\mathrm{i}} \mathrm{M}(\mathrm{s})><\mathrm{t}_{\mathrm{i}} \mathrm{C}(\mathrm{x})(1-\mathrm{s})$. Taxless finance works politically because it promises every district that its taxes will be lower if the project succeeds. ${ }^{14}$ Of course, a major element in whether these

\footnotetext{
${ }^{14}$ By 1830 , states were able to draw on 40 years of experience with investment in banks, with the expectation that " $\mathrm{M}$ " was positive and large, and that the probability of a successful investment, "s," was close to one. Canal investments in New York and Ohio had also proven
} 
schemes are perceived by citizens to have positive expected value depends on s, the probability of success.

As with benefit taxation, taxless finance can simultaneously satisfy the majority constraint and the exit constraint.

D. Many projects: Universalism or Something for Everyone. We emphasize the financing of a single large project because of its relevance for state transportation investments in the antebellum era. But the provision of small transportation projects was also relevant for federal investment. Many antebellum expenditure policies fell into this category, rivers and harbors projects, lighthouses, post offices, and roads.

One simple solution the legislature may chose, in contrast to building projects, is to provide funds to lower jurisdictions (e.g., grants by the Congress to the states; grants by state legislatures to counties or towns). Suppose that spending is allocated among districts by some formula or rule of thumb (such as equal grants per capita). Grant shares to individual districts are given by $g_{\mathrm{i}}$

$$
P_{i}(x)=b_{i}\left(g_{i} x\right)-t_{i} C(x) .
$$

Further suppose that at an arbitrarily small amount of spending, $\varepsilon$, produces net benefits for all districts:

$$
\mathrm{P}_{\mathrm{i}}(\varepsilon)=\mathrm{b}_{\mathrm{i}}\left(\mathrm{g}_{\mathrm{i}} \varepsilon\right)-\mathrm{t}_{\mathrm{i}} \mathrm{C}(\varepsilon)>0 \quad \forall \mathrm{i}
$$

profitable. Governor Ford of Illinois, spoke directly to the ex ante expectations of the Illinois politicians when he explained how the state got itself into difficulties in his message to the legislature of December 8, 1842 "No scheme was so extravagant as not to appear plausible to some. The most wild expectations were made of the advantages of a system of internal improvements, of the resources of the State to meet all expenditures, and of our final ability to pay all indebtedness without taxation. Mere possibilities appeared to be highly probable, and probabilities wore the livery of certainty itself." Quoted in House Document, p. 1051. 
Now the only problem facing the legislature is how much to spend. If the exit constraint is binding, expenditures will increase until the first district receives no net benefits. If the exit constraint can be eased by logrolling, then expenditures can increase further.

A simple virtue of something for everyone policies is that the same formula can often be used to allocate taxation and expenditures. For example, the constitution constrains the federal government to allocate direct taxes according to population. Direct taxes could be raised to finance expenditures and funds could be divided between states according to population, land area, miles of post roads, or some other easily measured attributes of states. Something for everyone policies often do not produce equal absolute of per capita grants for each state or county. The $t_{i}$ and $g_{i}$ need not be the same, they only need to be known.

Two other political forces push the legislature toward universal or something for everyone solutions. Consider a legislature facing decisions over a range of projects, each with concentrated local benefits and paid for through general taxation. ${ }^{15}$ For simplicity, we assume that each legislator has one proposed project; and that each project benefits her district and her district alone. ${ }^{16}$ Moreover, assume that each project is small relative to the budget, so that there is no problem financing many or all at the same time. Let the benefits to each district from its

${ }^{15}$ This subsection draws on the large literature on universalism, including Collie [1988], Inman and Fitts [1990], Niou and Ordeshook [1985], Shepsle and Weingast [1981], Stein and Bickers [1995], and Weingast [1979].

${ }^{16}$ Both of these restrictions are easily generalized, for example, to projects that benefit a small number of (perhaps contiguous) districts simultaneously. 
project be b; that these are identical across districts, as are all the costs, c; and that each district pays an equal tax share of $1 / \mathrm{n}$ of the total costs. ${ }^{17}$

Legislators now consider bundles of projects. Given each legislator's preferences, the ideal bundle of projects is simple to characterize. Each legislator receives positive benefits only if the project for her district is built. Building any or all other projects merely raises the district's taxes. So each legislator's ideal policy is to build her project alone. Unfortunately any legislation of that type will be defeated by a vote of $n-1$ to 1 , with only the legislator benefitting voting in favor. Legislators therefore have an incentive to create bundles of projects though logrolling.

The literature has studied two natural types of bundles or logrolls. The first is a minimum winning coalition (MWC) whereby $(\mathrm{n}+1) / 2$ legislators build their projects alone ${ }^{18}$ For those legislators whose projects are built, this maximizes their net benefits. Enlarging the coalition gains votes beyond the minimum needed. Yet, because it raises each coalition-members taxes without increase their benefits, each is worse off. Of course, those legislators not included in the MWC are worse off since their projects are not built, but they pay their share of the taxes to finance the MWC's projects. This implies that, once a given MWC forms, it is hard to overturn: all members of the coalition benefit from this bundle; no bundle makes them better off; and they are better off than if no projects are built.

\footnotetext{
${ }^{17} \mathrm{All}$ of these assumptions can easily be generalized, so that the benefits, $\mathrm{b}_{\mathrm{i}}$, costs, $\mathrm{c}_{\mathrm{i}}$, and tax share, $t_{i}$, differ across districts. As emphasized, we do not expect that these policies will produce equal absolute or per capita spending across states or counties. legislatures.

${ }^{18}$ Buchanan and Tulloch [1962] and Riker [1962] initiated the application of MWC's to
} 
The problem is that there are too many such coalitions, and ex ante no legislator is assured of being in the MWC so that their projects will be built. Thus, MWC politics involves risk.

As an alternative, the legislature might institute and enforce a policy of universalism, the notion that rather than play MWC politics, the legislature will simply build a project for each district. Various "universalism theorems" show that, in comparison to the uncertainty of MWC politics that build fewer projects than one for each district (but at least a majority), every legislator is better off under universalism [Niou and Ordeshook 1985, Shepsle and Weingast 1981, Weingast 1979]..$^{19}$

Although the proofs of these results are a bit technical, the intuition is straightforward. For simplicity, suppose that the benefits to each district, b, are identical, as are all the costs, c; and that each district pays an equal tax share of $1 / \mathrm{n}$ of the total costs. Under the MWC politics, legislators whose projects are built receive the benefits from their project, $b$, minus their share of the tax costs of $\mathrm{c}(\mathrm{n}+1) / 2$. As $\mathrm{n}$ becomes large, the size of the minimum winning coalition approaches $1 / 2$ of the legislature, so we will approximate the MWC tax share as one half; that is, c/2. Further, since no one knows which MWC will form, we consider each equally likely. This implies that a given legislator's chances of being in the MWC that forms is on the order of one half.

Thus, ex ante, each legislator's expected value of the uncertain MWC politics is $1 / 2[\mathrm{~b}$ $\mathrm{c} / 2$ ] (when district i's project is built) $+1 / 2(-\mathrm{c} / 2)$ (when district i's project is not built).

${ }^{19}$ One potential qualification of universalism that we ignore here is that universalism may apply within majority party only, so that projects are not built in districts represented by the minority party. 
Rearranging terms, the expected value of MWC politics is $1 / 2[\mathrm{~b}-\mathrm{c} / 2]+1 / 2(-\mathrm{c} / 2)=(\mathrm{b}-\mathrm{c}) / 2$. In contrast, under universalism, each district is assured its project, so the expected benefits are b-c. Because $b-c$ exceeds (b-c)/2 (as long as b-c $>0$ ), all legislators prefer to institute and maintain a set of institutions providing for universalism.

The universalism result shows that national expenditure programs can pass that provide large numbers of small projects, located across the country.

A second result concerns parties. if the coalitional structure is known in advance - e.g., a majority party or a region - then restricting universalism to that coalition provides its members with greater individual benefits to the party's members. Whether this happens depends on the geographic distribution of the majority party. If it is geographically concentrated, so that the minority is also geographically concentrated, financing the projects solely of majority party members is likely to violate the exit constraint.

The main point is that, when the legislature seeks to build large numbers of small projects, the tendency is toward universalism. We discussed two variants: with and without a majority party. Without a majority party, universalism is likely to hold. With a majority party, the oucome depends on geographic concentration. Without concentration, the majority party is likely to build projects solely for its members; but with concentration, doing so violates the exit constraint. If the exit constraint binds, majority parties are constrained from excluding the minority party.

E. Predictions about Legislative Choices. Governments could finance investments in transportation in four ways. Building a canal with limited geographic benefits was politically infeasible using normal taxation. Too many geographic interests obtained nothing except the 
prospect of higher taxes. Building transportation infrastructure with something for everyone policies was politically feasible, but fiscally impossible if the projects were large. New York could not afford to build an Erie Canal to every county. Universalist or something for everyone policies required equal, or close to equal, allocation of funds to every district. Small projects were politically feasible, but in the end did not develop an interregional transportation system.

A large canal investment could be made with benefit taxation or taxless finance. Benefit taxation worked very differently from taxless finance, however. Benefit taxation required that taxes be raised simultaneously with the onset of construction and borrowing. Taxless finance allowed taxpayers to assume a contingent tax liability, one that would only be assumed in the event the project failed. Both benefit taxation and taxless finance held out the promise of significant benefits. ${ }^{20}$ The constitutional restrictions placed on federal direct taxation made it difficult, if not impossible, for the federal government to use benefit taxation.

The following table summarizes the model's predictions. The national government is limited to taxless finance and universalist or something for everyone solutions. In contrast, states can use benefit taxation. Although universalist solutions are feasible for states, these are less attractive for major projects since this strategy necessarily involves building very small projects of limited value.

${ }^{20}$ Benefit taxation and taxless finance were not mutually exclusive policies, a state could use a little of each. Both benefit taxation and taxless finance legislation were easier to pass when there were large expected returns from the project. 
Prediction:

Normal taxation

Universalism/

Something for Everyone

Benefit Taxation

Taxless Finance
Federal No

Yes

No

Yes
State

No

Maybe

Yes

Yes

We turn next to the policies used by federal and state governments to finance investment between 1790 and 1860 .

\section{The Quantitative Pattern of Federal Internal Improvement Spending}

The rough outlines of federal transportation policy are given in table 1 and in figure 1 . Table 1 breaks down federal transportation expenditures by Presidential administration, both in aggregate and per capita terms. Figure 1 provides nominal federal transportation expenditures per capita, per year from 1790 to 1860 as well as transportation expenditures as a share of total federal expenditures.

The federal government spent money on transportation in every year in the early $19^{\text {th }}$ century and every Congress considered transportation legislation. As Figure 1 shows, nominal expenditures rose slowly from 1790 through the 1810 s, stalled during the early 1820 s, rose rapidly to a peak in 1837 , dropped back sharply to their 1810 s levels, then rose again in the 1850s. The picture is one of very small expenditures with only one significant expansion during the administration of Andrew Jackson. Nominal per capita income in 1840 was roughly $\$ 100$, so 
federal transportation expenditures in their highest year were only .1 percent of national income, and were typically on the order of .01 percent of national income. The federal government steadily spent a small amount of money on lighthouses, navigation improvements, and rural roads. Beyond that the federal government did very little.

\section{Assessing the model's predictions}

Our theoretical framework identifies four ways the federal government could have used to finance internal improvements. Table 2 compares the model's predictions about each method of finance with the amounts actually spent by the federal government. The main prediction is that the federal government will not finance transportation projects with normal taxation or benefit taxation, but will use taxless finance and universalism or something for everyone. The prediction is borne out. In total, 97 percent of all federal transportation expenditures were financed in using these two methods.

The federal government used something for everyone schemes to finance 68 percent of its infrastructure expenditures. Rivers and Harbors bills were the main legislative vehicle for funding these improvements. All the projects were small, and as was usually the case, individual bills embodied logrolling within one piece of legislation. ${ }^{21}$ The national government financed another 28 percent of expenditures with taxless finance. Most of the taxless finance schemes used public land and are discussed in detail below.

\footnotetext{
${ }^{21}$ The largest single federal project, aside from the Cumberland Road, was the Delaware breakwater, which received $\$ 2.1$ million in total. The breakwater funding was appropriated piecemeal, however, through rivers and harbors legislation.
} 
We now consider the different federal policies related to financing internal improvements and related programs.

Something for Everyone. Expenditures for lighthouses, roads, navigation, and general rivers and harbors accounts for the lion's share of expenditures made by the federal government between 1790 and 1860: $\$ 41,435,000$ out of $\$ 60,152,000$.

Normal taxation. Financing transportation expenditures through normal taxation was possible. In the Monroe and Adams administration, Congress appropriated funds to purchase stock in the Chesapeake and Delaware and Chesapeake and Ohio canals, as well as other smaller canals. Table 2 credits the $\$ 1,917,000$ for these canals entirely to normal taxation; about three percent of federal spending during the antebellum era. Normal taxation was possible, it just did not amount to much.

Benefit Taxation. The Constitution prohibited benefit taxation, which was not used.

Taxless Finance. Taxless finance includes land grants and other projects. Land grants came in two forms. One was land funds, in which a percentage of all revenue from federal land sales in public land states to those states was dedicated to building transportation projects to and within those state. The Cumberland Road stretched from Washington D.C. to Illinois and was the largest single federal project. The Road was initiated by the Enabling Act for Ohio in 1802, which set aside 2 percent of land sales revenues in Ohio to build roads to Ohio. Similar funds were established for other public land states (discussed in detail later). The second form of taxless finance using public lands were the direct grants of land to states like Indiana and Illinois for support of their canals. 
In the table, land grants included the land given to states (valued at $\$ 1.25$ an acre), the revenues from the land funds created in state enabling acts transferred to the states, and the expenditures on the Cumberland Road. The motivation behind land funds and outright grants to new states was explicitly fiscal. Land grant schemes were predicated on the expectation that the value of public land near the improvement would rise if transportation to an in the west improved. Land grant schemes illustrate the theoretical point that such ventures include a contingent form of liability. Land grants turned out, ex post, to cost federal taxpayers lost land revenues. Transportation improvements did raise land values, but higher land values did not translate into higher sale prices at federal land auctions after $1820 .^{22}$

Congress also used taxless finance in other ventures. In 1791 and 1816, the federal government chartered national banks. The First Bank was chartered with a capital of \$10 million of which the government subscribed \$2 million. The Second Bank was chartered with a capital of $\$ 35$ million of which the government subscribed $\$ 7$ million. In both cases, the government paid for its stock by issuing federal bonds to the banks (private subscribers could pay in specie or federal bonds). The banks paid dividends semi-annually, and the dividends paid to the federal government for its stock always exceeded the interest payments on the bonds the federal government used to purchase stock. This illustrates the principle of taxless finance: no taxpayer paid higher taxes because of the federal government investment in either Bank of the United States.

In 1862, the Union Pacific Railroad combined two forms of taxless finance, land grants and bond issues. The company's charter promised to give the railroad ten square miles of public

${ }^{22}$ Gates, [1968 and 1954]. 
land for every mile of railroad the company completed. ${ }^{23}$ In addition, the federal government would give the company $\$ 16,000$ in federal bonds for every mile of track completed. The bonds were an "ipso factor ... first mortgage on the whole line of the railroad and telegraph." The company was responsible for servicing the bonds and repaying the principle. ${ }^{24}$ Tax payers were not supposed to pay to service the bonds, and the value of federal lands were supposed to increase enough to outweigh the substantial acreage given to the railroad. The twists and turns of the Union Pacific are too complicated for us to follow. Suffice it to say in the end the federal government regretted that it had used taxless finance in this particular scheme.

\section{State Investment in Internal Improvements}

As noted, state investment in transportation outstripped federal investment by an order of magnitude. Goodrich estimates that state and local expenditures for transportation were a combined $\$ 450$ million before the Civil War, while federal government expenditures were $\$ 60$ million (Table 1). ${ }^{25}$

${ }^{23}$ The land was given in alternating one-square mile sections, in a strip ten miles to either side of the road. Land was transferred to the company after it completed each 40 mile long section of track. Section 3, An Act to Aid the Construction of a Railroad, $37^{\text {th }}$ Congress, 2nd Session, Chapter 120.

${ }^{24}$ Section 5, An Act to Aid the Construction of a Railroad, $37^{\text {th }}$ Congress, 2nds Session, Chapter 120.

${ }^{25}$ As noted earlier, we derive our $\$ 60$ million estimate from Senate Executive Document $190,42^{\text {nd }}$ Congress, $1^{\text {st }}$ Session. The $\$ 450$ million figure for state and local expenditure is a estimate made by Goodrich, Government Promotion. There is no breakdown on the total $\$ 450$ million that we can analyze by financing type. 
State budgetary data for the antebellum era are problematic and full accounting of state expenditures by function is not possible [Wallis, 2000]. One way to characterize state financial activity is to classify state debt outstanding in 1841 by type of financial method. The $\$ 198$ million outstanding in 1841 came just at the end of the dramatic expansion of state investment in canals, railroads, and banks in the 1830 s. Since states faced the same political constraints as the federal government -- a democratic legislature attempting to build geographically concentrated projects to satisfy geographically diverse constituencies - we expect to see the same pattern of outcomes with two differences. One, states are not prevented from using benefit taxation. Two, states are so small, with many numerous subdivisions (counties), that something for everyone is unlikely to be used to finance large projects, and small projects would be very small indeed.

Table 3 duplicates the structure of Table 2 for state government debt issued of outstanding up to 1841 . We are able to classify state expenditures for $\$ 183$ million of the $\$ 211$ million in debt issued up to $1841 .^{26}$ Almost all of the state borrowing was for large projects; no states borrowed to finance something for everyone schemes. ${ }^{27}$ Per the model's predictions, no large state projects were financed by normal taxation.

States financed \$53 million in canal investment through benefit taxation. New York included a provision allowing for a special "canal tax" in counties bordering the canal should canal tolls and other fiscal resources of the canal fund prove insufficient to service canal bonds.

${ }^{26}$ This section of the paper is based on Wallis, "Constitutions, Corporations, and Corruption." Debt outstanding in 1841 was \$198 million, and we have included \$13 million in canal bonds issued by New York and Ohio that had been repaid by the early 1830 s.

${ }^{27}$ States did, however, use formulas extensively to finance education expenditures and to distribute road funds, but because these expenditures were not financed by debt issue they are not included in the table. 
Ohio, Indiana, and Illinois moved explicitly to ad valorem property when they adopted their canal systems. ${ }^{28}$

States financed another \$53 million in bank investments using taxless finance. Southern states used several variants of the method used to finance the Second Bank of the United States. The states purchased stock in banks by issuing bonds that the banks were responsible for servicing. States had been successfully investing in banks in the United States since the 1780s. ${ }^{29}$

The final $\$ 80$ million were financed by taxless finance as well, only this borrowing was primarily for transportation. After the success of the Erie Canal, states like Pennsylvania and Maryland began borrowing to build canals, but did not raise tax rates. Instead, they paid current interest on their bonds out of bond premiums or out of current borrowing. Pennsylvania was the worst state in this regard, and by 1841 it had the largest debt of any state, $\$ 33$ million. New York began borrowing in the late 1830s to expand the Erie network, and did not raise taxes when it did so. When New York, 1817, and Ohio, 1826, began borrowing to build canals they used benefit taxation. When Pennsylvania and Maryland began borrowing in 1828 they utilized

\footnotetext{
${ }^{28}$ See Wallis, 2003, for detailed consideration of the role that ad valorem property taxation played in Indiana, and an over view of actions in the other states.

Property taxes were the major source of income for most state and local governments in the early $19^{\text {th }}$ century, Wallis [2000 and 2001]. As Heckelman and Wallis [1997] show, late $19^{\text {th }}$ century state and local investment in railroads made sense from a benefit tax point of view, even though many railroads defaulted on their obligations. State and local governments received more in property tax revenues than they paid in debt service. Much of the state and local provision of transportation was generically, if not explicitly as in Indiana, benefit taxation.

${ }^{29}$ For state involvement in banking see Wallis, Sylla, and Legler [1994]. In the 1810s, Massachusetts began taxing bank capital, well as investing in banks. When the state realized the capital tax was more remunerative than dividends, it sold its bank stock. By the 1830 s, more than half of all Massachusetts state revenue came from the tax on bank stock. Pennsylvania receive roughly a quarter of its state revenues from bank dividends and bonus fees for bank charters.
} 
taxless finance, partly because it was clear by 1828 that the Erie Canal was returning profits to New York. When Indiana and Illinois began borrowing in 1837 they too used benefit taxation. But when New York and Massachusetts started borrowing in the late 1830s they used taxless finance. The use of taxless finance for transportation investments only arose after it appeared that those investments would be profitable.

State investments were remarkable. In 1836 and 1837, Indiana, Illinois, and Michigan, with a combined population of slightly more than 1,000,000 people, authorized the issue of over \$25 million in state bonds. This debt exceeded the entire federal expenditures for transportation in the Jackson and Van Buren administrations combined. All of the state internal improvement spending in the 1830 s was financed by benefit taxation or taxless finance, just as the model predicts.

\section{Presidential Vetoes of Federal Legislation}

Column 2 of Table 2 reflects actual federal expenditures, which requires approval of both the Congress and the president (subject to the veto override qualification). The table and our discussion has left out legislation passed by Congress but vetoed by the president. As these proposed significant expenditures, we examine them to see how they conform to the model's predictions. First, we study the substance of the failed legislation, including analysis of the first proposal for a systematic federal internal improvements policy. Second, we estimate the impact of this legislation on federal expenditures. Because some of the legislation includes multi-year 
schemes for distributing funds from future revenues, we construct a counterfactual pattern of federal expenditures assuming that the vetoed legislation had in fact become law.

Congress considered proposals for a variety of transportation projects every year, but acted on them only episodically. ${ }^{30}$ As documented, most of the money the federal government spent was appropriated through small rivers and harbors bills. On occasion, however, national debates occurred resulting in legislation that, had it not been vetoed, would have given the federal government a larger, permanent transportation policy. These major episodes are listed in Table 4. The episodes underscore the historical inability of the federal government to implement a larger program, and show that the logic of our approach helps understand the federal government's impotence.

The federal government passed on four opportunities to create a major transportation policy. The first began with Jefferson's second inaugural speech in 1805 when the President encouraged Congress to consider spending the budget surplus on transportation projects. This led Congress to commission the Gallatin plan, which in 1808 laid out a $\$ 20,000,000$ program of eight major national improvements. The Gallatin plan was derailed in part by Congress's inability to pass any of the pieces of the plan as individual projects and in part by financial costs of Embargo of 1808 and the War of 1812. As our model predicts, Congress could not appropriate money for large projects a one or two at a time. ${ }^{31}$

\footnotetext{
${ }^{30}$ Curtis Nettels [1924] analyzed the votes on 117 pieces of internal improvement legislation considered by Congress between 1815 and 1829 alone.

${ }^{31}$ The history of internal improvements is impressive. Goodrich [1960], Harrison [1954], and Larson [2002] provide comprehensive accounts of federal policy. The citations to these three sources are given in this and the next section can be used to track the larger literature. For the Gallatin plan see Goodrich [1960], 26-28 and Larson [2002], 58-63.
} 
The second episode occurred when Congress decided in 1817 to allocate the $\$ 1,500,000$ bonus paid by the Bank of the United States to a fund for internal improvement by proposing first to divide these funds among the states on the basis of population, and second to contribute future dividends from the Bank to the fund. In one of his last acts as President, Madison vetoed the Bonus Bill. ${ }^{32}$ Madison supported a constitutional amendment to allow the federal government to support transportation, but would not approve grants for transportation without an amendment. $^{33}$

The third episode encompassed Andrew Jackson's first term and his decision to "oppose" to internal improvements. Jackson vetoed the Maysville Road bill in $1830 .{ }^{34}$ The Maysville road lay entirely in Kentucky (and was the route that Jackson's arch rival, Henry Clay, took home from Washington) and was one of several small transportation bills passed by Congress that year. Jackson vetoed these bills on the grounds that the road did not serve a national purpose. Nonetheless, Jackson spent more on transportation than any President up to the Civil War, much of it on projects similar to the Maysville road. We examine his well publicized opposition to internal improvements later.

Then, in 1833, Clay negotiated an end the Nullification crisis, which included three bills: the Force Bill, allowing Jackson the power to enforce national legislation, a tariff bill that lowered rates, and a distribution bill allocating federal land sales revenues among the states on

${ }^{32}$ Distribution bills typically divided money between the states on the basis of population or on the basis of representation in Congress. Since every state had at least 3 members of Congress, allocation of funds on the basis of Congressional representation had a small state bias.

\footnotetext{
${ }^{33}$ For Madison's veto see Goodrich [1960], 37-38; Larson [2002], 63-69.

${ }^{34}$ For the Maysville veto see Goodrich [1960], 41-45 and Larson [2002], 182-186.
} 
the basis of Congressional representation. Jackson signed the Force Bill and the tariff bill, but pocket vetoed the distribution bill, the last act of his first term [Larson 2002, 187-191.]

The final negative episode occurred when Henry Clay managed to include another distribution provision in the Land Bill of 1841, automatically distributing public land sales revenues to the states by Congressional representation. The distribution scheme, however, was tied to the tariff. If tariff rates increased, distribution would be canceled. President Tyler signed the Land Bill and shortly thereafter raised the tariff and suspended distribution.

Of the four major setbacks to a larger federal transportation program, only the failure to enact the proposals of the Gallatin plan involved what we have termed normal taxation. As predicted, Congress could not pass such a plan. The other three setbacks involved Presidential vetoes, or adverse action, of something for everyone plans. What the president's vetoed would not have created a large integrated national transportation system, since all of the money in the vetoed bills would have been spent by the states without any federal supervision.

How important were the vetoes? The last column of Table 2 presents a simple counterfactual allocation of the spending that would have occurred had legislation not been vetoed. All of the vetoed legislation would have resulted in something for everyone/universalistic grants to states, and significantly, the main conclusion that we draw from Table 2, that the federal government could not use normal taxation or benefit taxation to finance transportation expenditures, remains unchanged by the counterfactual.

The table assumes that the entire $\$ 1,500,000$ bonus paid by the Second Bank of the United States as well as dividends of $\$ 700,000$ a year (a 10 percent return on the government's $\$ 7,000,000$ investment) for twenty years totaling $\$ 14,000,000$ would have been distributed to the 
states. Had interest on the federal bonds used to purchase the stock been netted out, this figure would have been reduced to roughly $\$ 7,000,000$.

The impact of the distribution bills of 1833 and 1841 are estimated by taking half of actual gross land sales revenues between 1834 and 1841 (for the 1833 bill) and half of actual gross land sales revenues from 1842 and 1860 (for the 1841 bill). Both bills would have netted out the costs of the land office before grants were made to the states. By coincidence, nominal land sales revenues between 1833 and 1841 are the same as nominal revenues between 1841 and 1860 (a testament to the unusual sales in 1835 and 1836). One needs to be careful with this counterfactual, however. If the distribution bill of 1833 had not been vetoed, then the land sales revenues that accumulated in the federal treasury and were distributed in 1837 would never have accumulated. ${ }^{35}$ Since $\$ 27,000,000$ was actually distributed to the states, the $\$ 42,000,000$ figure for the 1833 act requires adjusting to $\$ 15,000,000$ if we take into account the surplus distribution that did occur.

The impact of the vetoed legislation is large in absolute terms: federal expenditures on transportation would have been two and-a-half to three times higher (by $\$ 97,500,000$ or $\$ 70,500,00$ depending on how the surplus revenue is treated.) Of course, none of this money would have been spent by the federal government, it all would have been spent by the states. There still would not have been a federal system of internal improvements. Our prediction that the federal government will use something for everyone/universalistic expenditure programs still

${ }^{35}$ In 1836, Congress passed and Jackson signed a bill distributing the federal surplus revenue to the states. It was to be done in four quarterly installments, totaling $\$ 36$ million over the course of 1837. The Panic of 1837 disordered federal finances, and the fourth installment was never made. See Bourne [1885]. 
stands as verified. Even with the addition of $\$ 70,000,000$ in federal grants to the state, federal expenditures would have been less than a third of state and local governments between 1790 and 1860.

\section{Antebellum Federal Internal Improvement Spending}

The federal government did have accomplishments. The first was funding lighthouse construction, beginning with the first Congress in 1790. Funding small, geographically diverse projects continued on an annual basis, with the addition of roads in 1802, rivers in 1824, harbors in 1824 , and the first "rivers and harbors" bill in $1826 .{ }^{36}$ Small omnibus lighthouse, roads, and rivers and harbor legislation account for $\$ 41$ million of the $\$ 60$ million in federal transportation expenditures (Table 2). Funding for universal collections of transportation projects was continuous and, with the exception of Jackson's 1830s vetoes, never frustrated by the president.

The second important federal initiative, and the second most important in fiscal terms, began in 1802 with the enabling act admitting Ohio to statehood. This act set aside five percent of land sales revenues, after deducting expenses, for the "building of public roads" to and within

\footnotetext{
${ }^{36}$ Goodrich, [1960], p. 40. See Malone, Opening the West, and Senate Executive Document 196, $47^{\text {th }}$ Congress, ${ }^{\text {st }}$ Session, "Statement of the Appropriations and Expenditures for Public Buildings, Rivers and Harbors, Forts, Arsenals, Armories and Other Public Works from March 4, 1789 to June 30, 1882." Malone's book analyzes the information in the Report. He comes up with a total of $\$ 54$ million on transportation expenditures. Our calculations total $\$ 60$ million. We have chosen to go with our total and have been unable to determine where Malone derived his \$54 million total from.
} 
the state of Ohio. ${ }^{37}$ The Ohio legislature asked that three percent of the funds be expended inside Ohio and Congress agreed. The "two percent" fund for roads leading to Ohio began to accumulate, and in 1805 Congress authorized a survey of the route for the National, or Cumberland, Road. Construction began in 1808, and continued into the 1850 s, in the end accounting for $\$ 7,000,000$ in expenditures. ${ }^{38}$

The Ohio enabling act is remarkable for several reasons. First, similar provisions were included in the enabling acts of every state that entered the Union after Ohio. ${ }^{39}$ Second, the act clearly authorized the federal government to redistribute funds from one revenue source, sale of public lands, to another expenditure purpose, public roads (that were not post roads which were explicitly authorized in the Constitution]. Third, the act authorized the construction of public roads within one state, with the consent of the state. In other words, the Ohio enabling act put policies into place that were repeated in the enabling act of every subsequent state by Congress and signed into law by Presidents. Yet Madison, who signed state enabling acts with these provisions, and Jackson vetoed bills containing exactly the same procedures and policies on the grounds that the bills were unconstitutional. Madison and Jackson did not use the term "unconstitutional" in a consistent way.

The third positive accomplishment developed in the administrations of Monroe and John Quincy Adams. Although a supporter of internal improvements, Monroe vetoed a bill

${ }^{37}$ The arrangement was an explicit deal in which Congress agreed to build roads to and within Ohio in return for Ohio's promise not to tax federal lands for five years after they were sold to private individuals. Larson [2002], 54-55.

${ }^{38}$ Goodrich, 1960, pp. 24-26.

${ }^{39}$ Terms of the other enabling acts varied slightly, but contained the same principles. See Gates [1968]. 
authorizing the construction and maintenance of toll booths on the Cumberland Road in 1822 .

On the same day that he issued his veto, he seemed to slam the door on federal internal improvements in a long message to Congress arguing that federal improvements required a Constitutional amendment. But then, reversing his position, Monroe indicated in his seventh annual message to Congress (December 1823] that he would support projects of "a national object. ${ }^{40}$ In 1824, Congress passed and Monroe signed a General Survey bill authorizing the Army Corp of Engineers to begin surveying possible transportation routes to build an integrated national system. On his last day in office in 1825, Monroe authorized federal subscription of $\$ 300,000$ in the stock of the Chesapeake and Delaware Canal. His successor, John Quincy Adams, laid out an ambitious agenda of federal expansion in his first message to Congress. Adams vigorously supported transportation projects, and by the end of his administration the federal government had subscribed $\$ 1,921,000$ to the stock of the Chesapeake and Delaware canal, the Louisville and Portland Canal, the Dismal Swamp Canal, and the Chesapeake and Ohio (C\&O) canal.

Federal stock subscription was a form of normal taxation. Regular federal revenues, mainly from tariffs, were used to purchase stock (in the 1820 s it was surplus revenues, no new taxes were levied or raised). Adams was demonstrably willing to sign bills authorizing normal taxation, but despite active presidential support, Congress could not come up with an integrated

${ }^{40}$ For Monroe's veto message see Richardson, Papers and Addresses of the Presidents, "Veto Message," May 4, 1822, pp. 711-12. For his message suggesting that truly national projects should be supported see Richardson, Papers and Addresses of the Presidents, "Seventh Annual Message," December 2, 1823, p. 785. For the Monroe and Adams administrations see Goodrich [1960], 38-40 and Larson [2002], 135-173. 
plan for a national transportation system. All four of the stock subscriptions were in projects originally identified in the Gallatin report in 1808 .

Congress instead pressed ahead with universal spending and a version of taxless finance. The first rivers and harbors bill passed in 1826. In the same year, Congress approved a series of land grants to individual states for the support of specific projects in Ohio, Indiana, Illinois, and Alabama. These land grants conferred to states the opportunity to sell public lands and use the revenues to support projects. Congress explicitly considered this a form of taxless finance. Even though the federal treasury gave up land revenues on the granted lands, Congress fully expected that transportation improvements would raise the value of adjacent lands. Grants were made in alternating strips on either side of the transit line, federal lands alternating with state lands (this was the origin of the land grant system used to finance the intercontinental railroads). The striking outcome of the Monroe and Adams presidencies is the small amount of funding forthcoming from Congress, less than $\$ 2$ million of funds from normal tax revenues. Something for everyone and taxless finance were still the order of the day.

Jackson is credited with ending federal support for transportation. As Goodrich put it, "the Era of National Projects may be thought of as ending in his administration." [Goodrich 1960, p. 42.] But as Table 1 makes clear, Jackson was not against federal support for transportation in general, and his administration spent more money on transportation than any other before the Civil War. Although Jackson's expenditures were matched in nominal terms by administrations of Pierce and Buchanan, he spent a far larger percentage of federal expenditures on transportation than any other president. What Jackson killed when he vetoed the Maysville road was the idea of an integrated national system of internal improvements. This goal is what 
Monroe started towards in the General Survey Bill in 1824 and what Adams hoped to accomplish.

Jackson had the luck to be in office during the largest public land boom in the nation's history, 32 million acres of land were sold in 1835 and 1836, generating $\$ 40$ million in revenue alone when expenditures in 1830 were only $\$ 15$ million. While he opposed a integrated nationally financed system of internal improvements, Jackson had no problem with approving expenditures for light house, road, and rivers and harbors legislation that Congressmen loved and had been passing since the 1790s. Political historians have long appreciated Jackson's creation of a political party mechanism that enforced party loyalty in the Congress. The dramatic expansion in internal improvement funding surely helped Jackson and his party leaders to assemble and maintain this coalition. Jackson's handpicked successor, Van Buren, had the unfortunate luck to come into office just as the economy headed into six years of economic upheaval and depression.

\section{Extensions: The $20^{\text {th }}$ Century Growth of the Federal Government}

Given our thesis about the impotence of the antebellum federal government, a natural question to ask next is why did the federal government grow to be so large in the twentieth century? A detailed explanation is beyond the scope of this paper, but our model sheds lights on this question. The key historical episodes occurred in the Civil War and New Deal, but part of the power of the federal government still lies in its ability to pursue something for everyone policies. 
The first important difference between the antebellum and postbellum years is that the Civil War dramatically altered the exit constraint. Secession from the Union became far more costly, so the threat of exit became much less serious. During the Civil War, Southern secession immediately altered the section balance and geographic competition within Congress. Southern absence allowed Northern representatives to take action several measures previously held up by sectional differences, including the intercontinental railroad and the Homestead Act.

The federal government gradually increased the size and scope of its operations in the late $19^{\text {th }}$ and early $20^{\text {th }}$ century, but the federal government did not grow relative to state and local governments until the New Deal [Wallis 2000]. The Great Depression triggered a substantial increase in the size of government at all levels, but particularly at the federal level. Increased expenditures on various relief programs comprised the bulk of the relative increase in federal expenditures [Wallis 1984].

The expansion of relief and infrastructure spending combined with the increase in economic regulation to dramatically increase the possibilities for legislative exchange and log rolling within Congress: simultaneously expanding the scope of government in many areas allowed the Democratic party to engineer a more complex set of political exchanges underpinning the New Deal whereby all Democrats gained from the new set of programs. The model shows that adding a single new program with concentrated benefits is very difficult. Yet adding a large set of new programs with different incidences allows members of Congress to support a package of programs that make them better off.

A second factor emphasized by our model also promoted federal expansion namely, the power of universalism or something for everyone. The largest federal transportation program is 
the interstate highway system. Federal grants for highway construction began in 1916. To this day, highway grants reflects a formula-driven program that provides something for everyone [Johnson and Libecap, 2003]. Highway grants are a classic case of universalism: every state shares in the expenditures. New Dealers also funded welfare expenditures in a something for everyone form. The Social Security Act passed in 1935 created a multi-dimensional relief structure. Old age insurance (Social Security) was funded through individual accounts, the ultimate in something for everyone. Categorical relief programs - Aid to the Blind, Old Age Assistance, and Aid to Dependent Children - were financed with straight matching grants depending on state spending per case. Unemployment Insurance was funded through a federal payroll tax, but administered by state governments. All these programs provide funds to categories of individuals who reside in every state and every congressional district. In essence, all of the money to be spent under the Social Security Act, by the far the act with the largest fiscal implications in the nation's history, was allocated by something for everyone type formulas. ${ }^{41}$ Even in the $20^{\text {th }}$ century, therefore, the federal government funds a great many expenditures through something for everyone programs.

In combination, then, the Civil War relaxed the exit constraint and the New Deal provided the opportunity for a new set of political exchanges underpinning a dramatic expansion in the federal government.

\footnotetext{
${ }^{41}$ Medicare, the other big national entitlement, also provides something for everyone in
} the sense the program provides benefits for individuals in every state. 


\section{Conclusions}

The central puzzle of this paper concerns why the states and not the federal government were the primary locus of the promotion of economic development during the antebellum era. States spent an order of magnitude more than the national government in providing various forms of economic infrastructure, notably, roads, canals, railroads, lighthouses, harbors, and banks. We demonstrate that while these programs were popular with the voters, states and not the federal government provided these public goods. Moreover, we show that the federal government regularly sought to promote them. While states financed huge transportation projects, the federal government's aggregate spending was not only much smaller, but typically focused on small projects, such as building lighthouses and dredging harbors, rather than on large and arguably more valuable projects.

To solve this puzzle, we provide a model of political choice based on the theory of legislative choice. The model yields several conclusions concerning the financing of large projects - where large projects are defined as those whose financial commitments are so large that only one or two can be built at once. First, legislatures have difficulty voting to fund large projects because the benefits are typically concentrated, while the expenses are spread over all through general taxation. This means that a majority of districts receive no direct benefits from the project and yet pay their share of the costs. Because their net benefits are negative, these districts oppose building the project.

Second, benefit taxation affords a potential way out of this problem. Benefit taxation sets a district's taxes in proportion to the benefits it receives, so that districts with the most benefits 
pay the most taxes while districts receiving no benefits pay no taxes. Projects with perceived positive expected values can be financed in this way because there is no natural opposition.

Third, majority rule legislatures easily finance large packages of small projects; that is, simultaneously building many small projects in most or nearly all districts. This includes the standard rivers and harbors projects, lighthouses, post offices and postal roads. In contrast to a single large project, large packages of small projects gain majority support by including projects for most or nearly all districts,.

The final piece of the puzzle is institutional: The United States Constitution created an asymmetry between the national and the state governments with respect to taxation. Although states were free to use benefit taxation, the Constitution prohibited the national government from using it: the Constitution requires that all direct taxes be in proportion to the federal ratio.

These results help explain the pattern of governmental expenditure in antebellum America. First, the huge demand for market-enhancing public goods promoting economic development through infrastructure was quite popular with national and state voters. Yet the Constitutional asymmetry on benefit taxation implied that states were able to use this financial mechanism to create majorities in favor of large projects, whereas the federal government was not. Although proposals for promoting systematic, interregional infrastructure development regularly came to the Congress, few passed. The national government did, however, spend a considerable amount funding large collections of small projects, such as lighthouses, postal roads, and dredging harbors.

Three implications of our approach provide insights into the growth of the federal government in the twentieth century. First, the Civil War dramatically reduced the importance of 
the exit constraint, allowing concentration of benefits by a majority. Second, although the model shows that it is difficult to add a single new program with concentrated benefits, it is possible to add a large set of programs as long as the incidence of the set makes a majority better off. Third, a great many of the New Deal programs were based on universalism or something for everyone. The New Deal combined all these features to help underpin the great expansion of the federal government.

An additional benefit of our approach concerns the issue of federalism. A major concern in the literature on federalism concerns the question of what provides for federalism's stability. As Riker [1964] observed, most federal states fail, either by disintegrating or by becoming centralized ones. In order for federalism to be stable, it must be self-enforcing in the sense that government both national and subnational government officials have the incentive to abide by the restraints of federalism [de Figueiredo and Weingast, 2005].

A major issue in the economic and political history of the early nineteenth century is why the national government was relatively small in comparison to the states. Our approach shows that the Constitution provided a structure that allowed states to finance infrastructure projects but not the national government. This effect helped keep the national government smaller and the states larger. Were the national government able to use benefit taxation, it would have undoubtedly been far larger and the state governments far smaller. 


\section{References}

Aldrich, John H. 1995., Why Parties? The Origin and Transformation of Party Politics in America. (Chicago: University of Chicago Press.)

Bourne, Edward G., The History of the Surplus Revenue Act of 1837. (Original published in 1885. Reprinted by Burt Franklin: New York, 1968.)

Buchanan, James, and Gordon Tullock, Calculus of Consent. (Ann Arbor: University of Michigan Press, 1962.)

Callender, Guy Stevens, "The Early Transportation and Banking Enterprises of the States." Quarterly Journal of Economics, vol. XVII, no. 1, (1902), 111-162.

Collie, Melissa, "The Legislature and Distributive Policymaking in Formal Perspective." Legislative Studies Quarterly. 12 (1988), 427-58.

Cox, Gary W., and Mathew D. McCubbins, Legislative Leviathan. (Berkeley: University of California Press, 1993).

Cox, Gary W., and Mathew D. McCubbins, Setting the Agenda. (Cambridge: Cambridge University Press, 2005).

de Figueiredo, Rui, and Barry R. Weingast, "Self-Enforcing Federalism,” J. of Law, Economics and Organization, 2005.

Gates, Paul Wallace, History of Public Land Law Development. (Washington, D.C.: GPO, 1968.)

Gates, Paul Wallace, “The Railroad Land-Grant Legend.” Journal of Economic History, 14 (Spring 1954), 143-46.

Goodrich, Carter, Government Promotion of American Canals and Railroads. (New York: Columbia University Press, 1960.)

Harrison, Joseph Hobson, The Internal Improvement Issue in the Politics of the Union, 17831825. (Unpublished PhD Dissertation, University of Virginia, 1954.)

Heckelman, Jac and John Joseph Wallis, "Railroads and Property Taxes" Explorations in Economic History, 34, (January 1997), 77-99.

Hendrickson, David C., Peace Pact: The Lost World of the American Founding. (Lawrence: University Press of Kansas, 2003.) 
Hinich, Melvin J., and Micahel C. Munger Analytical Politics. (New York: Cambridge University Press, 1997.)

Inman, Robert P., "Federal Assistance and Local Services in the United States: The Evolution of a New Federalist Fiscal Order," in Harvey S. Rosen, ed., Fiscal Federalism: Quantitative Studies. (Chicago: University of Chicago Press, 1988.).

Inman, Robert P., and Michael Fitts, "Political Institutions and Fiscal Policy: Evidence from the U.S. Historical Record.” J. of Law, Economics, and Organizations, 6 (1990), 79-132.

Johnson, Ronald N. Gary D. Libecap, "Transaction Costs and Coalition Stability under Majority Rule.," Economic Inquiry, 41 (April 2003), 193 - 207.

Krehbiel, Keith, “Where's the Party?” British J. of Political Science (1994).

Larson, John Lauritz. Internal Improvement: National Public Works and the Promise of Popular Government in the Early United States. (Chapel Hill: University of North Carolina Press, 2001).

Legler, John B., Richard E. Sylla, and John Joseph Wallis, "U.S. City Finances and the Growth of Government, 1850-1902," Journal of Economic History, 48, (June 1988), 347-356.

Malone, Laurence J., Opening the West: Federal Internal Improvements Before 1860. (Westport, CT: Greenwood Press, 1998.)

Nettels, Curtis, "The Mississippi Valley and the Constitution, 1815-1829." The Mississippi Valley Historical Review, 11 (December, 1924), 332-357.

Niou, Emerson, and Peter Ordeshook, "Universalism in Congress." American J. of Political Science, 298 (1985), 246-90.

North, Douglass C., The Economic Growth of the United States, 1790-1860. (New York: Norton, 1966).

Polsby, Nelson W., How Congress Evolves: Social Bases of Institutional Change. (New York: Oxford University Press, 2004).

Richardson, James D., Messages and Papers of the Presidents, (Washington: Bureau of National Literature, 1897).

Rohde, David. Parties and Leaders in the Postreform House. (Chicago: University of Chicago Press, 1991). 


\section{Federal Impotence}

Riker, William H., The Theory of Political Coalitions. (New Haven: Yale University Press, 1962).

Riker, William H., Federalism: Origins, Operations, and Significance. (Boston: Little, Brown, 1964.)

Schickler, Eric., Disjointed Pluralism: Institutional Innovation and the Development of the U.S. Congress. (Princeton: Princeton University Press, 2001).

Schlesinger, Arthur Meier, "The State Rights Fetish," in his, New Viewpoints in American History. (New York: Macmillan,1922).

Shepsle, Kenneth A., “The Textbook Congress.” 1989.

Shepsle, Kenneth A., and Mark S. Bonchek, Analyzing Politics. (New York: W.W. Norton, 1997).

Shepsle, Kenneth A., and Barry R. Weingast, "Political Solutions to Market Problems," American Political Science Review, 78 (June 1984), 417-34.

Stein, Robert M., and Kenneth N. Bickers, Perpetuating the Pork Barrel: Policy Subsystems and American Democracy. (New York: Cambridge University Press, 1995).

Stewart, Charles III, Analyzing Congress. (New York: W.W. Norton, 2001).

Sylla, Richard, John B. Legler, and John Joseph Wallis, "Banks and State Public Finance in the New Republic." Journal of Economic History, 47 (1987), 391-403.

Taylor, George Rogers. The Transportation Revolution, 1815-1860. (New York: Harper, 1968).

Wallis, John Joseph, Richard Sylla and John Legler, "The Interaction of Taxation and Regulation in Nineteenth Century Banking.” In Goldin and Libecap, eds. The Regulated Economy: A Historical Approach to Political Economy, (Chicago: University of Chicago Press, 1994), 121-144.

Wallis, John Joseph, "The Birth of the Old Federalism: Financing the New Deal," Journal of Economic History, 44 (March 1984) 139-159.

Wallis, John Joseph, “The Property Tax as a Coordination Device: Financing Indiana's Mammoth System of Internal Improvements.” Explorations in Economic History, 40 (July 2003) 223-250. 


\section{Wallis and Weingast}

Wallis, John Joseph, “American Government Finance in the Long Run: 1790 to 1990,” Journal of Economic Perspectives, 14 (January, 2000), 61-82.

Wallis, John Joseph, "History of the Property Tax," in Property Taxation and Local Government Finance, Wallace E. Oates, ed., (Cambridge, MA: Lincoln Institute, 2001).

Wallis, John Joseph, “Constitutions, Corporations, and Corruption: Constitutional Change in American States, 1842-1852.” Journal of Economic History, 65 (March 2005), 211-256.

Weingast, Barry R., "A Rational Choice Perspective on Congressional Norms," American Journal of Political Science 24 (1979), 245-262.

Weingast, Barry R., and William H. Marshall, "The Industrial Organization of Congress: Or Why Legislatures, Like Firms, Are Not Organized as Markets" Journal of Political Economy. 96 (1988), 132-63.

Weingast, Barry R., Kenneth A. Shepsle, and Christopher Johnsen. "The Political Economy of Benefits and Costs: A Neoclassical Approach to Distributive Politics," Journal of Political Economy, 89 (August 1981), 642-664.

Wood, Gordon S. Creation of the American Republic. (Chapel Hill: University of North Carolina Press, 1969). 


\section{Federal Impotence}

Table 1

Federal Spending on Internal Improvements by President

\begin{tabular}{lrrrr} 
Administration & \multicolumn{1}{l}{ Dates } & \multicolumn{1}{l}{ Aggregate } & Per Capita & \multicolumn{2}{c}{$\begin{array}{c}\text { Share of all } \\
\text { Federal Expenditure }\end{array}$} \\
& & & & \\
Washington & $1788-1796$ & $\$ 229,968$ & $\$ 0.009$ & $0.74 \%$ \\
J Adams & $1797-1800$ & $\$ 303,896$ & $\$ 0.015$ & $0.94 \%$ \\
Jefferson & $1801-1808$ & $\$ 994,678$ & $\$ 0.020$ & $1.36 \%$ \\
Madison & $1809-1816$ & $\$ 2,066,910$ & $\$ 0.033$ & $1.52 \%$ \\
Monroe & $1817-1824$ & $\$ 2,997,914$ & $\$ 0.042$ & $5.87 \%$ \\
J Q Adams & $1825-1828$ & $\$ 3,861,265$ & $\$ 0.083$ & $9.51 \%$ \\
Jackson & $1829-1836$ & $\$ 14,452,376$ & $\$ 0.129$ & $5.62 \%$ \\
Van Buren & $1837-1840$ & $\$ 7,528,064$ & $\$ 0.118$ & $3.47 \%$ \\
Harrison/Tyler & $1841-1844$ & $\$ 3,068,753$ & $\$ 0.042$ & $2.29 \%$ \\
Polk & $1845-1848$ & $\$ 3,197,824$ & $\$ 0.038$ & $4.33 \%$ \\
Taylor/Fillmore & $1849-1852$ & $\$ 4,071,541$ & $\$ 0.043$ & $3.51 \%$ \\
Pierce & $1853-1856$ & $\$ 9,642,863$ & $\$ 0.091$ & \\
Buchanan & $1857-1860$ & $\$ 9,515,536$ & $\$ 0.080$ &
\end{tabular}


Wallis and Weingast

Table 2

Model Predictions and Federal Spending Patterns

Method

Prediction

Amount

Cases

Veto

Counterfactual

Normal Taxation

No

$\$ 1,917,000$

Chesapeake and

Delaware

Chesapeake and Ohio

Something for Everyone Yes

Small Projects

$\$ 41,435,000$

Unspecified Navigation

Rivers

Harbors

Aids to Navigation

Internal Navigation

Miscellaneous Roads

Distribution

Bonus Bill

Dividends

$\$ 1,500,00$

1833 Distribution Bill

$\$ 14,000,000$

1841 Distribution Bill

$\$ 42,000,000$

$\$ 42,000,000$

$\begin{array}{ll}\text { Benefit Taxation } & \text { No } \\ \text { Taxless Finance } & \text { Yes } \\ & \text { Big Projects }\end{array}$

0

$\$ 4,750,000 \quad$ Public Land Funds

$\$ 6,800,000 \quad$ Cumberland Road

$\$ 5,250,000$

Land Grant

Equivalents

(4,000,000 acres)

Total

$\$ 60,152,000$

Other Taxless Finance

\begin{tabular}{|c|c|}
\hline$\$ 2,000,000$ & $\begin{array}{l}\text { First Bank of the } \\
\text { United States }\end{array}$ \\
\hline$\$ 7,000,000$ & $\begin{array}{l}\text { Second Bank of the } \\
\text { United States }\end{array}$ \\
\hline 30.000 .00 & Union Pacific Railroac \\
\hline
\end{tabular}




\section{Federal Impotence}

Table 3

Model Predictions and State Spending Patterns

$\begin{array}{llll}\text { Method } & \text { Prediction } & \text { Amount } & \text { Cases } \\ \text { Normal Taxation } & \text { No } & 0 & \\ \text { Something for Everyone } & \begin{array}{l}\text { Yes, but Unlikely } \\ \text { Projects are too } \\ \text { small }\end{array} & 0 & \text { Some education and roads } \\ \text { Benefit Taxation } & \text { Yes } & \$ 53,000,000 & \text { Canals and RR, in NY, OH, IN, IL } \\ \text { Taxless Finance } & \text { Yes } & \$ 53,000,000 & \text { Banks in South } \\ & & \$ 80,000,000 & \text { Transportation in North } \\ & & & \\ \text { Total } & \$ 186,000,000 & \end{array}$

Source: Wallis, "Constitutions, Corporations, and Corruption." 
Wallis and Weingast

Table 4

Major Episodes in Federal Transportation Policy

Year

1802

1805

1817

1821

1825

1825

1828

1830

1832

1836

1841
Program

Ohio Enabling Act allocates 5 percent of land sales in Ohio to building transportation to and within Ohio. The federal portion, 2 percent, forms the basis of the fund for constructing the Cumberland Road

Jefferson's Second Inaugural Speech Led to Gallatin Plan in 1808

Bonus Bill:

Distribute the $\$ 1,500,000$ charter bonus and subsequent dividends from the Bank of the United States to the States on the basis of Congressional representation

Monroe vetoes bill to repair Cumberland Road toll booths, but then promotes and signs General Survey Bill.

JQ Adams supports a larger federal system in his inaugural speech.

Congress funds the Maysville road along with several other small road projects.

Congress passes a distribution bill, allocating a portion of federal land sales revenues to the states as part of Clay's compromise package to end the Nullification crisis.

Congress votes to distribute federal surplus revenues to the states on the basis of Congressional representation, but not to tie the distribution to transportation.

Congress includes a provision to distribute a portion of federal land sales to the states in the Land Bill of 1841, but includes a proviso that ties distribution to the level of the tariff.
Result

Required $2 \%$ of land sales in Ohio to be dedicated to building a road to Ohio. Eventually resulted in $\$ 8,000,000$ in expenditures on the Cumberland Road

Relatively little federal action. Most of Gallatin's proposed projects were built by the states

Vetoed by President Madison

The survey bill results in surveys, and Monroe approves stock purchase in C\&D canal.

Congress debates plans, and implements several large land grant projects and four stock purchases.

Jackson vetoes the Maysville Road bill.

Jackson signs the force bill and the tariff bill, but pocket vetoes the distribution bill.

Jackson signs the bill and $\$ 24,000,000$ is distributed to states in 1837 . The fourth installment is never made.

Tyler raises tariffs and suspends distribution. 
Federal Impotence

Figure 1 Federal Internal Improvement Expend

Per Capita and Share of Total Expend

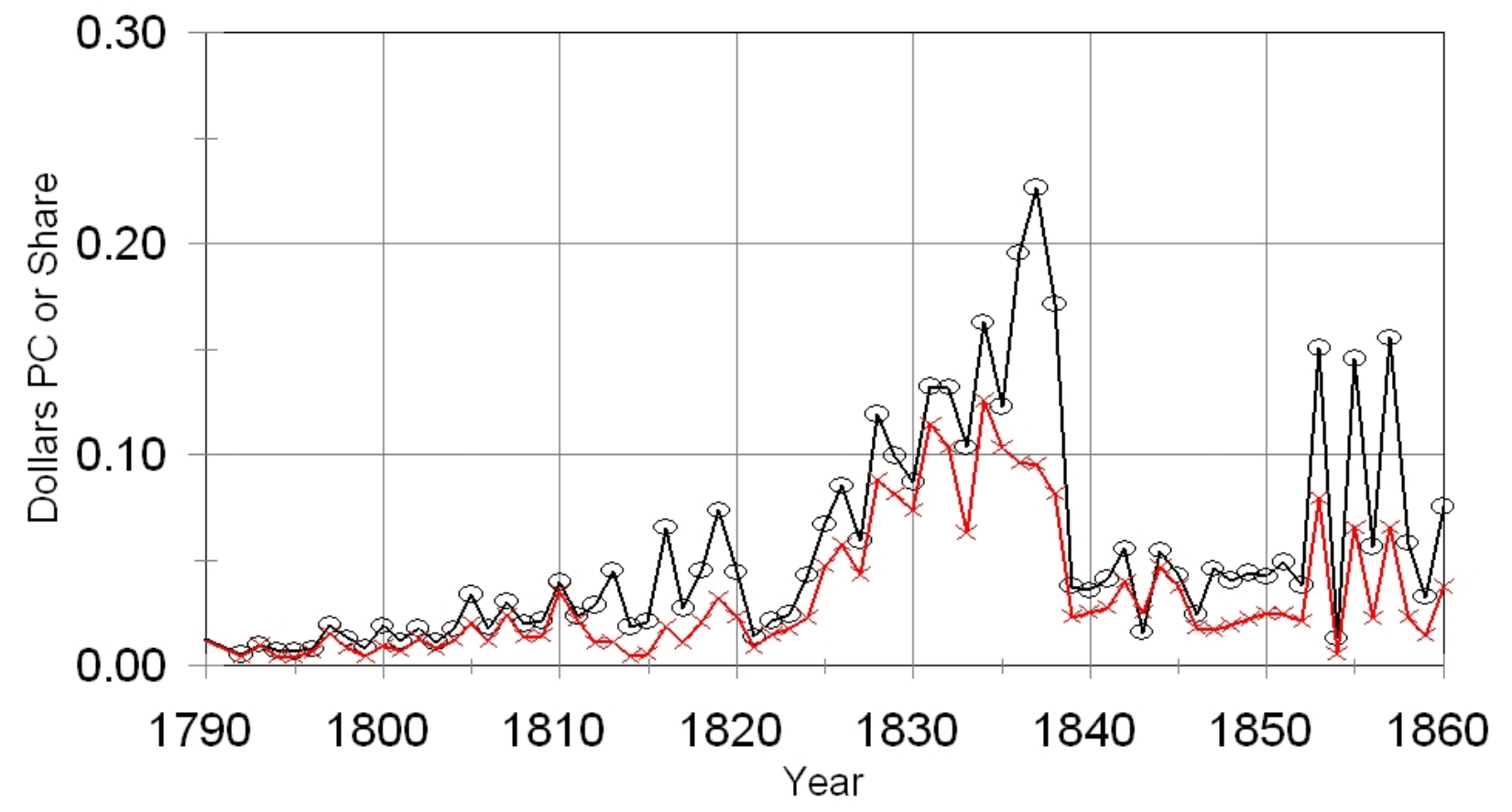

$\multimap$ cents $\rightarrow$ share 